\title{
Haberciliğin Değişen Pratikleri: Çoklu Ortam, Çoklu Yetenek, Çevrimiçi Gazetecilik
}

Aysel ÇETiNKAYA, Kocaeli Üniversitesi, İletişim Fakültesi, Gazetecilik Bölümü, Dr. Öğr. Üyesi, aysel.cetinkaya@kocaeli.edu.tr.

İhsan KARLI, Kocaeli Üniversitesi, İletişim Fakültesi, Gazetecilik Bölümü, Doç. Dr., ikarli@kocaeli.edu.tr.

ÖZ

\begin{abstract}
İletişim ve bilgi teknolojilerinde yaşanan gelişmeler birç̧ok alanda olduğu gibi gazetecilik alanında ve gazetecilik mesleğinin standartlarında birtakım değişikliklere sebep olmuştur. Birden fazla medyanın tek bir araçta toplanmasını ve kullanılmasını să̆layan yeni medya, bu özelliği ile çoklu ortam (multimedia) niteliği taşımaktadır. Çoklu ortam içerik üretiminin bir gereği olarak, gazetecilerin bütün medya araçlarına yönelik olarak bir dizi yetenek geliştirme ihtiyaçlarını ortaya çıkarmaktadır. Artık gazetecilerin bir içeriği toplama, değerlendirme ve yazma gibi temel gazetecilik görevlerinin yanı sıra o içeriğge uygun fotoğrafı seçme ve düzenleyebilme, gerekirse bir fotoğraf galerisi oluşturabilme, video içeriği üretebilme ve o haberin okur kitleye ulaşmanı sağlama gibi becerileri edinmesi beklenmektedir.

$B u$ çalı̧̧ma, gazetecilik mesleğinin değişim yapısının haber üretim sürecinde meslek pratiklerinin nasıl evirildiğini ele almayı amaçlamaktadır. Çalışmanın verileri, gazetecilik mesleği, çevrimiçi gazetecilik ve çoklu yetenek konularındaki literatür taramasıyla birlikte 1 Mayıs-30 Haziran 2018 tarihleri arasında yüz yüze görüşme tekniğiyle ve e-posta kanalıyla görüşme yapılarak toplanmıştır. Araştırmanın örneklemi uzman örneklem tekniğine bağh olarak, çevrimiçi gazetecilik endüstrisine ve ekonomisine yön verdiği düşünülen çevrimiçi gazetelerin yayın yönetmenleri ve gazetecilik mesleğini aktif olarak icra etmiş, mesleğin geçmişi ve bugünü konusunda deneyim sahibi gazetecilerdir. Yönetici sınıfin görüşlerine başvurmak, çevrimiçi gazetelerin işleyişini ve üretimini sürdüren işgücünde aradıkları niteliklerin tespit edilebilmesi; mesleğe yılların vermiş gazeteciler ile görüşülmesi ise geçmişte gazetecilerde aranan özelliklerin ortaya konulması açısından önem kazanmaktadır.
\end{abstract}

Anahtar Kelimeler: Gazetecilik, çevrimiçi gazetecilik, çoklu ortam, çoklu yetenek

\section{Changing Practices of Journalism: Multimedia, Multiskilling, Online Journalism}

ABSTRACT The developments in communication and information technologies have led to several changes in the journalism area and in the standards of the journalism practice, as well as in many areas. The new media, which enables the collection and use of multiple media in a single tool, has the characteristic of multimedia with this feature. As a requirement to produce multimedia content, journalists need to develop a range of capabilities for all media tools. Other than the basic journalistic tasks like collecting, evaluating, and writing content, journalists now are 
expected to acquire skills such as selecting and editing the proper photo, creating a photo gallery if necessary, producing video content, and ensuring that the news reaches the audience.

This study aims to discuss how the changing structure of the journalism has changed the vocational practices in news production. It is aimed to collect the data with the face-to-face interview technique and a literature review in the journalism profession, online journalism, and multiskilling subjects, and the research sample is determined by the expert sampling technique from the purposeful sampling methods from 1 May to 30 June 2018. Depending on the expert sampling technique, the research sample consists of the editors-in-chief of online newspapers leading the online journalism industry and the economy, and journalists who have actively engaged in the journalism profession and have experience in the past and present of the profession. Asking opinions of the executives, determining the qualities that the online newspapers look for in the workforce that continues its functioning and production, meeting journalists who have given years to this profession has gained importance to be able to find the characteristics required in journalists in the past.

Keywords: Journalism, online journalism, multimedia, multiskilling

\section{GíRiş}

Toplum içindeki bireylerin birbirlerinden haber alma isteği, gazetecilik mesleğinin doğuşundaki en önemli faktörlerden biri olmuştur. Gazeteci toplumu ilgilendiren önemli konuları tespit edip onu haber haline getirerek toplumu bilgilendirir. İnsanları öğrenmeye ve gündemi takip etmeye yönlendirirken, kamuoyu oluşturmaya da aracılık etmektedir.

Modern gazetecilik tüm dünyada endüstrileşme ile gelişmiştir. Erken dönem gazeteler çoğunlukla yayıncı ya da matbaa sahipleri tarafından yönetilirken, kuruşluk gazetelerle birlikte, basın sektöründe iş bölümleri oluşturulmaya başlanmış; gazetenin sahibi, içerik üretmek için çalışan gazeteciler ve teknik personel arasında iş bölümü yaratılmıştır. Endüstrinin diğer bölümlerinde olduğu gibi, iş bölümü gazeteleri hiyerarşik şekilde örgütlenen organizasyonlar haline getirmiştir. Gazeteciler de kendi içlerinde muhabirler, editörler, fotoğrafçılar, tasarımcılar gibi ayrışmışlardır.

Gazetecilerin çalışma şekli, son on ila on beş yıl içerisinde hızla değişime uğramıştır. Dijital teknolojiler gazetecilere yeni araçlar kazandırmış ve buna bağlı olarak haber merkezi süreçlerinde de değişimler yaşanmıştır. Bu süreçte, ana akım medya kuruluşları kendi yayınlarını dijital ortama taşırken, bir de hiçbir medya şirketine bağlı olmayan sadece çevrimiçi mecrada doğan ve hayatını bu ortamda sürdürmeye çalışan haber siteleri ortaya çıkmıştır.

Tüm bu gelişmelerin gazetecilik çalışmalarını ve gazetecilerin profesyonel rollerini nasıl etkilediği merak edilen bir konu olmuştur. Gazetecilik ve gazetecilik değerleri hakkında düşünmeyi gerektiren yeni günlük çalışma rutinleri ortaya çıkmıştır. Bu süreçte bazı araştırmacılar, teknolojik değişimin iş pratiğini, kaynakların rolünü ve haber içeriklerini 
nasıl etkilediği gibi soruları ele alan araştırmalara ihtiyaç duyulduğunu vurgulamışlardır (Cottle, 2003; Schudson, 2005). Haber üretimi sosyolojisi 1970'lerde ABD'de geliştirilmiştir (Gans, 1978; Tuchman, 1978) ve o zamandan bu yana, haber üretimi uygulamalarının nasıl değiştiğine dair derinlemesine analizlerin yapılmasını gerekli kılmıştır.

\section{1. Çalışmanın Amacı ve Yöntemi}

Değişen teknoloji ile birlikte özellikle gazetecilik alanında kamu hizmeti yapan gazetecilerin çalışma şekli ve iş ilişkileri de değişim göstermektedir. Gazetecilik mesleğinin tanımı değişmese de işin yapılma boyutu, biçimi son on yıl içerisinde çok hızlı bir şekilde değişim göstermektedir. Dolayısıyla bu değişen teknolojiyle beraber habercilik mesleğinin de değişiminin bizzat çalışanlarla görüşülerek ortaya konulması bu çalışmada amaçlanmıştır.

Haber üretiminde çoklu yeteneğin varlığının, olumlu ya da olumsuz yanlarının tespit edilebilmesi için iki farklı yarı yapılandırılmış soru formu hazırlanmıştır. Çevrimiçi gazetelerin üst düzey yöneticileri ve çalışan gazeteciler olarak iki farklı grup aktör olarak alınmıştır. 1 Mayıs-30 Haziran 2018 tarihleri arasında sekiz yüz yüze görüşme yapılmış, kaydedilmiş ve yazıya dökülmüştür. Görüşülen iki kişi çevrimiçi gazetelerin üst düzey yöneticileri, dört tanesi ise aktif olarak muhabirlik ya da editörlük yapan gazetecilerdir. Görüşülen kişiler; www.yenisafak.com İnternet Yazı İşleri Müdürü Ersin Çelik, www.haberturk.com eski Genel Yayın Yönetmeni Yardımcısı Barış Erkaya, Star gazetesi editörü Şener Kılıç, Milliyet gazetesi editör ve yazarı Mustafa Anıklı, ve ikisi de TRT ve NTV kurumlarında çalışan muhabirlerdir. İki tane de emekli gazeteci ile görüşülmüştür. Bazı görüşmeciler isimlerinin açık yazılmasını tercih etmediğinden, çalışmada o kişilerin sadece ünvanları ve görevleri yazılmıştır.

Katılımcılardan çoklu yetenek konusuna nasıl baktıkları, zaman içerisinde gazetecilerden beklenen beceri yeterliliklerinin nasıl değiştiği, teknolojik yöndeşmenin gazetecileri nasıl etkilediği sorularını yanıtlamaları istenmiştir. Aşağıdaki tartışma, tanımlanan bir dizi ortak temanın detaylı okunmasına dayanmaktadır.

\section{Gazetecilikte Çoklu Ortam Kullanımı}

Bilgisayar ve ağ teknolojilerinin gelişimi hiç şüphesiz habercilik mesleğindeki çalışma biçimlerini ve pratiklerin değişimini de beraberinde getirmiştir. Medya son on yllda çoklu ortam (multimedia) silsilesinin içine girmiştir. Bu bağlamda çoklu ortam kavramı ele alındığında; yazı, ses, fotoğraf, video, grafik, animasyon ve etkileşimin (interaktiflik) bir uyum içerisinde kurgulanmasıyla oluşmaktadır. Bu unsurlar, ihtiyaca göre seçilmeli ve özenle birleştirilmelidir. Bir fotoğraf karesiyle anlatılabilecek bir olay sayfalarca yazı ile anlatılamayabilecekken bazen de tek bir paragraf okurların aklındaki soru işaretlerini giderebilir (Muhabir Habercinin Temel Kitabı, 2018: 181).

Çoklu ortamın gazetecilik mesleğinin iş yapma pratiklerini hızlandırdığı ve içeriği zenginleştirdiği ifade edilmektedir. İçerik internet gazetelerinde hem metinsel, hem görsel hem de işitsel olarak farklı formatlarda sunulabilmektedir. Bu hem çevrimiçi gazeteler 
arasında rekabeti arttırmakta hem de konvansiyonel medyadan farklı içeriklerin sunulmasına yol açmaktadır.

Çoklu ortamı etkili kılan en önemli unsur etkileşimdir. Kullanıcının istediği bilgiye, istediği yolla ve yöntemle ulaşması, alacağı bilgiyi daha kolay anlamlandırmasına yardımcı olmaktadır. Gerçek bir ses, grafik ya da video görüntüsü ile aktarılabilen bir ifade metin yerine kullanıldığında eldeki malzeme daha verimli kullanılmış olur. Ancak metinsel ifadelerin, açıklayıcı ve bütünsel gücünün de farkına varılmalıdır (Muhabir Habercinin Temel Kitab1, 2018: 181-182).

Multimedya gazeteciliği /haberciliği diye bir kavram ortaya çıkmıştır. Ancak, yarının gazetecilerinin, basılı, yayın veya çevrimiçi medyada çalışıp çalışmadıklarına bakılmaksızın, farklı medya türlerine aşina olmaları gerektiğinden şüphe yoktur. Çevrimiçi habere yönelik iş modellerinin zayıflı̆̆ nedeniyle, çoğu ana akım medya bir sinerji stratejisi benimsemiştir. Çevrimiçi operasyonların basım ve yayın haber merkezleri ile birleştirilmesi gerekmiştir. Bu amaçla medya kuruluşlarının çoğu haber merkezlerinin örgütsel yapısını değiştirmiştir, böylelikle gazeteciler çoklu platformlar için içerik üretebilir hale gelmiştir.

Haber merkezi birleştirmeleri, yöndeşme ve çoklu ortam kullanımı gibi özellikler gazetecilerin çalışma pratikleri ve gereken mesleki becerileri üzerinde önemli bir etkiye sahip olmuştur. Bu durum, gazetecilerin hiç olmadığı kadar çok yönlü olmalarını gerektirmiştir. Her ne kadar eski kuşaklar bu yeni çalışma ortamına uyum sağlama konusunda daha az istekli olsalar da, multimedya üretimi video ve fotoğraf düzenleme gibi görevleri beraberinde getirmektedir (Saltzis, 2012: 469).

Giderek artan sayıda gazetecinin, çoklu dağıtım platformları için çoklu medya formatında (metin, ses, fotoğraf ve video), gazete, televizyon ya da radyodan kurumun web sitesine, mobil haber servislerine, bloglara ve sosyal medyaya kadar içerik üretmesi gerektiği söylenebilir. Gazetecilerin her zaman "çok görevli" olmadıkları ve çoğu gazetecinin halen tek bir medyada "uzmanlaşmaya" odaklandığı vurgulanmaktadır (Lee-Wright, Philips \& Witschge, 2011: 79; Raeymaeckers, Paulussen ve De Keyser, 2012), fakat tekliortamdan (monomedia) çoklu ortam (multimedia) haber kültürüne geçildiği açıktır. Yöndeşik haber merkezleri bağlamında düşünüldüğünde çoklu yeteneğin önemi yadsınamaz bir gerçektir.

Çevrimiçi gazetecilikle birlikte gazetecilerde aranan özelliklerde de birtakım değişimler yaşanmıştır. Sosyal medya kullanımı, hızlı düşünebilme, görsel seçebilme, video kurgulayabilme, internet sayfasına yükleme yapabilme gibi yeterlilikler aranan niteliklerin başında gelmektedir.

Haberturk.com eski Genel Yayın Yönetmeni Yardımcısı Barış Erkaya artık bir muhabire nasıl haber yaptıklarını sormaktan ziyade teknolojiye ve sosyal medyaya olan ilgilerini de sorduklarını ifade etmektedir: "Sosyal medyayı ne ölçüde kullandığını ölçmeye çalışıyorum. Çünkü sosyal medya artık haber kaynağı olarak çok önemli. Gazetecilik güdülerini ilk harekete geçiren mecra artık sosyal medya. Ajanslardan bile hızlı. Ajansların dünyadan haberi bile olmayabiliyor. Ama gazeteciliğin temel prensipleri, double check, haberin 
doğruluğunu sorgulama vs. bunlar değişmedi. Sosyal medyaya ilgisi nasıl, nasıl takip ediyor, benim için bunlar önemli... Kimleri takip ediyor? Gereksiz 5000 kişiyi mi takip ediyor? Kendisine takip listeleri hazırlıyor mu? Görsel yönü nasıl onu anlamaya çalışıyorum. ... Bir haberi yazan kişinin aynı zamanda o haberin görselini de en iyi şekilde seçmesini istiyorum. Artık kapak üstü yazılar otomatik olarak çıkabiliyor ama biz bunu terk etmedik. Sürekli olarak bunu tercih etmiyoruz. Gazetecinin kendisinin photoshopla kapak üstüne yazı yazmasını istiyoruz. Kapağı hazırla gönder bakalım diyoruz. Videosunu da bulsun istiyoruz."

Yenisafak.com internet yayın yönetmeni Ersin Çelik de bir muhabirden haberi yazmanın dişında fotoğraflamak, son okumasını yapıp manşete taşımak ve varsa videosunu kurgulamak ve sosyal medyada paylaşımını yapmak gibi beklentilerinin olduğunu söylemektedir. Gazeteciler bunun internetin ve teknolojinin getirdiği bir durum olduğunu düşünmektedir.

Yapılan görüşmeler, gazetecilerde aranan niteliklerin çoklu ortamın özelliklerine uygun olarak değiştiğini göstermektedir. Haber yazmaya ek olarak, o haberin görselini seçmek, gerekirse düzenlemek, videosunu kurgulamak gibi teknik beceriler aranmaktadır. Sosyal medya kullanımı ön plana çıan gerekliliklerden bir tanesidir. Çünkü sosyal medya platformları, çevrimiçi haber içeriklerinin dağıtımındaki en önemli araçlardır.

\section{Gazetecilik Pratiğinin Dönüşümü: Çoklu Yeteneğe Sahip Gazeteciler}

Teknolojik yöndeşme ve yeni medyanın özelliklerinden olan çoklu ortam, gazetecilerin mesleki pratikleri ve gereken mesleki becerileri üzerinde önemli bir etkiye sahip olmaktadır. Artık günümüzde gazetecilerin hiç olmadığı kadar çok yönlü olmaları gerekmektedir. Her ne kadar eski gazeteciler bu sürece ayak uydurmakta zorlansalar da, multimedya üretimi bu tür çoklu görevleri gerekli kılmaktadır.

Çoklu yeteneğe sahip bir gazeteci, bir haber içeriği oluştururken video çekimi, röportaj, fotoğraf çekimi, hikayeyi yazma, ses ve video düzenlemesi yapma gibi çeşitli işlevleri yerine getirebilmektedir. Gazeteciler ve akademisyenler genellikle bu tür gazetecileri "sırt çantası gazetecileri" (Stone, 2002; Gordon, 2003) ya da "Müfettiş Gadgetler" (Quinn, 2005: 31) olarak tanımlarlar. Ve ünlü bir atasözü ile bu durum pekiştirilir "her şeyin ehli, hiçbir şeyin ustası (jack of all trades, master of none)" (Singer, 2004; Tanner ve Duhe, 2005; Huang vd., 2006). Burada hakim olan eleştiri, her şeyi yapmaya çalışan bir gazetecinin hiçbir şeyde gerçekten iyi olmadığıdır. Bu argümanlar, karşıt argümanlarla karşılansa bile hala yaygındır (Erdal, 2009a).

Çoklu yetenek kavramı tüm organizasyonlarda tek tip bir kavram olarak karşımıza çıkmamaktadır. Öncelikle bazı organizasyonlarda gazetecilerin birden fazla çıktı için çalışması gerekmektedir. $\mathrm{Bu}$, web ve basılı nüsha için yazma becerisinin oldukça benzer olduğu gazetelerde daha yaygındır. Çoklu formatta haber üretimi (yani metin, ses, video), gazetecilerin "multimedya gazetecileri" olarak anılmalarına da neden olmaktadır. Günümüzde gazeteciler, haberlerini daha fazla multimedya özelliğiyle buluşturmak durumunda kalmaktadırlar. Çünkü çevrimiçi mecradaki çoğu haber, metin ve görsel-işitsel 
materyali içermektedir. Ayrıca gazetecilerden geçmişte teknik personelin yaptığı görevleri de üstlenmeleri beklenmektedir. Kullanıcı dostu dijital teknolojiler sayesinde, videoları ya da sayfaları biçimlendirmek daha kolay hale gelmektedir. Gazetecilerin işine eklenen yeni görevler, özellikle web için içerik oluşturma ve düzenleme ile ilgilidir. Web sitesi için son dakika haberlerini, blog yazmayı, ses ve video yakalamayı, podcast oluşturmayı, canlı sohbet oturumlarına katılmayı ve fotoğraf çekmeyi içermektedir. Gazeteciler de bu dönüşümün farkındadır ve bir muhabir bu durumu şöyle ifade etmektedir: “Gazetecilik, belli bilgi ve becerinin yanı sıra, dünyadaki gelişmeleri yakından takip etme ve sürekli yenilenmeye ihtiyaç duyulan bir meslek dalıdır. Yazılı basın ve uzun yıllar süre gelen tek kanallı görsel medyanın ardından önce radyo akabinde de özel TV'ler ve internet medyası, gazetecilerin kendilerini sürekli olarak geliştirmeleri gereğini getirmiştir. Gazeteciler artık mevcut becerilerinin yanı sıra video ve ses düzenleme, kurgulama, web tasarımı, grafik ve animasyon yapabilme ve bunları sunabilme yeteneklerine sahip olmaya zorlanmaktadır" (NTV Muhabir).

Bu oluşumun, özellikle son dakika haberlerini anında verebilmek için geliştirilen programlar sayesinde, ajanstan gelen haberi daha basit bir edit işleminin ardından yayına sunulmasına olanak sağladığını ifade eden Star Gazetesi Editörü Şener Kılıç çoklu ortamın kısa sürede okuyucuya ulaşma konusunda katkı sunduğunu belirtmektedir: "Metin, ses, görüntü, fotoğraf, animasyon gibi öğeleri bir araya getiren oluşum sayesinde haberciler, masa başındaki bilgisayarı üzerinden saniyelerle sınırlı bir sürede okuyucu/ izleyiciye ulaşabilmektedir. Haberlere hızı erişim aynı zamanda güncelleme imkanı da sağlamaktadır."

Wilkinson vd.'leri çoklu yetenege sahip gazetecileri tanımlamak için 'multimedia journalistçoklu ortam gazetecisi” kavramını kullanmaktadırlar. Gazetecilerin her alanda uzman olamayacaklarını fakat bu alanla ilgili temel ilkeleri bilmeleri gerektiğini vurgulamaktadırlar. $\mathrm{Bu}$ temel ilkeler şunlardır (Wilkinson, Grant ve Fisher, 201: 37-45): (1) Yeniden yazma/düzeltme: Bir gazeteci bir yazıyı kaleme alırken hangi bilgileri içereceğini, video, ses ve/veya fotoğraf galerisi olup olmaması gerektiğini ve ayrıca hikayeyi etkili bir şekilde nasıl kurgulayacağını bilmelidir. Bununla birlikte dosyanın zamanlamasının da iyi yapılması gerekmektedir (2) Fotoğraf: Fotoğraf çekebilmek her gazetecinin en temel becerilerinden biridir. Çevrimiçi gazetecilikte görsellik ön plana çıktığı için fotoğraf önemlidir. (3) Video: İyi bir video çekimi fotoğrafta olduğu gibi fokus, ışık ve çerçevelemeye bağlıdır. Ancak çerçeveleme video görüntulerinde fotoğraftakinden daha önemlidir. Bir gazetecinin videonun çekilmesi kadar düzeltilmesini de bilmesi gerekmektedir. Hikayeyi doğru ve haber içeriğine uygun şekilde vermelidir. (4) Grafik tasarım: Grafikler, sayısal verilerin kullanımında, olayların ve yerlerin resimlendirilmesinde, haberin hikayesi ve nesneler arasındaki ilişkilerin ş̧malandırılmasında ya da hikayenin önemli noktalarının vurgulanmasında önemlidir. Yöndeşik gazetecinin elbette bir grafik sanatçısı olmasına gerek yoktur ancak hikayeyi zenginleştirmek ve karışık ögeleri sadeleştirmek için grafik tasarım bilmelidir. (5) Web tasarımı: Çoğu haber organizasyonu web sitesinin görünürlügü ve sürdürulebilirligi için profesyonel tasarımcıları bünyesinde bulundurmaktadır. 
Saltzis ve Dickinson (2008), yaptıkları araştırmada iki farklı gazeteci gelişimini öngörmüşlerdir. Bunlardan ilki yüksek gazetecilik standartları içerisinde değerlendirilecek tek yetenekli uzman gazeteciler, diğeri ise çok yönlülüğe ve şartlara kolay uyum sağlayabilen çoklu yeteneğe sahip gazetecilerdir. Ayrıca, gazetecilerin işlerinin çok fazla yönünü kontrol atına aldıkları ve yakın geçmişe kıyasla daha geniş bir beceri yelpazesine sahip olduklarını iddia etmektedirler.

Çoklu yetenek kavramı gazeteciler tarafından ise internet ve yeni medya ile ilişkilendirilmektedir. Hatta internet haber editörlüğü olarak tanımlayan gazeteciler vardır. "Bir editör için; hem haber yazıp hem yayınlayıp hem de kamera karşısına geçip sunma şeklinde açabiliriz bu tanımı. Benim böyle çalışma arkadaşlarım var." (Yenisafak.com İnternet Yazı İşleri Müdürü Ersin Çelik).

Haberi içerik olarak değerlendirmesinin yanında biçimsel olarak değerlendirilmesi de önem kazanmaktadır. Dijital dünyada içeriğin biçimsel olarak da göze hitap etmesi gerekmektedir Haberturk.com eski Genel Yayın Yönetmeni Yardımcısı Barış Erkaya'nın görüşleri şu şekildedir: "Görsel işitsel olarak bir haberi işleme yeteneğine sahip olmasını istiyorum. Bu pratikte herkes için mümkün olamiyor. Bir haberi gördüğü anda bu haber sosyal medyada bu haber çok güzel infografik olarak sunulabilir diyebilecek insanlarla da çalışıyoruz.".

Aslında Türk basınında da bu çoklu yetenek arayışının uzun süredir var olduğu görülmektedir. Türkiye Gazeteciler Sendikası eski başkanlarından Ercan İpekçi bu konudaki görüşlerini şu şekilde aktarmaktadır: "Devasa medya towerlara doldurdukları insanları şimdi daha küçük mekanlarda daha fazla iş yükleyerek çalıştırma yolunu seçtiler. Bundan dolayı gelecekte ne olabilir? Dünyadaki bir eğilim bir gazeteciye bir çok gazetecinin farklı görevlerini yüklemek. Fotoğraf çektirmek, görüntüyü de çektirmek gibi bir eğilim var. Ama bunu genelleştiremezler. Bu türden çok yönlü muhabirlerin çoğunluğa ulaşması mümkün değil. Yine de bir grubun bu şekilde istihdam edilmesi eğilimi var" (Akt. Karahisar, 2012: 104). Karahisar bu durumun iş dünyasında 2000'li yılların başından beri rastlanan bir durum olduğunu, işverenlerin daha az personel istihdam etmek için "çok yönlü" eleman arayışı içine girdiklerini ifade etmektedir. Yazılı basında çıkan iş ilanları incelendiğinde işverenlerin çalışanlarının hem genç, hem de bir çok konuya vakıf olmalarını istediği görülmüştür. Özellikle de gençler iş bulabilmek için seminer ve kursalar düzenleyen kurumların yolunu tutmaktadir (2012: 104).

Yeni medyanın gazetecilik pratiği üzerindeki etkisi, nihai haber ve çalışma rutinlerindeki değişimleri gösteren ve gazeteciler ile hedef kitleleri arasında ortaya çıan yeni ilişkileri tartışan bir dizi çalışma ve bakış açısıyla incelenmiştir (Pavlik, 2001; Fenton, 2010). Bu ampirik çalışmalarla belirlenen önemli değişiklikler, haberlerin etkileşimli doğası, haber toplama ve raporlamadaki değişimler üzerinedir. Görüşmecilerden biri bu düşünceyi destekler nitelikte görüş bildirmiştir: “En önemli haber kaynaklarımızdan bir tanesi sosyal medya editörlerimiz. An be an kim ne paylaştı onu gördükleri için onlardan gelen geri bildirimlerle yaptığımız haberlerin sayısı ve dikkat çekiciliği o kadar fazla ki tutup da bunun kaliteyi düşürdüğünü söyleyemem, tam tersine haber çeşitliliği ve kalitesini arttırdığını düşünmekteyim." (Haberturk.com eski Genel Yayın Yönetmeni Yardımcısı Barış Erkaya). 
Yeni medyanın sahip olduğu çoklu ortam, hiperlink (hipermetin), etkileşim, kolay ölçümlenebilir olma gibi özellikler, gazetecilerin iş yapma pratiklerini de etkilemektedir. Örneğin kariyer.net sitesinde 19 Eylül 2018 tarihinde yayınlanan bir internet editörü ilanı için işin tanımı şöyledir: "Ajanslardan, muhabirlerden, internet vb. haber kaynaklarından gelen haberleri değerlendirecek, gerektiğinde haber yazacak, sayfa düzenlerini oluşturup, resimleri buna göre sayfaya yerleştirecek İnternet Editörü alınacaktır." Bu tanımda görüldüğü üzere, çeşitli kaynaklardan gelen haberleri değerlendirip düzenleme işlevi ön plana çıkmaktadır. Haber yazma görevi ise "gerektiğinde" denerek ikincil plana atılmaktadır. Habere uygun fotoğraf seçilmesi ve internet sayfasına yerleştirilmesi de işin birincil tanımı içinde yer almıştır.

Aynı ilandaki istenen yetenekler ve uzmanlıklar ise şöyle sıralanmıştır: (1) Üniversitelerin tercihen İletişim, Basın-Yayın, Gazetecilik bölümlerinden mezun, (2) Alanında en az 3 yıl deneyimli, (3) Haber diline hakim, araştırmayı seven ve gündemi aktif olarak takip eden, (4) Sosyal medyaya dair temel bilgisi olan, (5) Canlı haber takibi yapabilen, (6) SEO (search engine optimisation-arama motoru optimizasyonu) uyumlu olarak haber ve makale yazımı, içerik editörlüğü alanlarında tecrübeli, arama trendlerini yakından takip eden, (7) Tercihen İngilizce bilen, (8) Esnek çalışma saatlerine uyum gösterebilecek, (9) Ekip çalışmasına yatkın, (10) Erkek adaylar için askerlik görevini tamamlamış, (11) Gazeteciliğe uygun haber başlıkları ve özetleri yazabilen çalışma arkadaşları arıyoruz (Kariyer.net, 19 Eylül 2018). Aranan niteliklerin başında, iletişim mezunu olma kriterinin gelmesi dikkat çekicidir. Haber diline hakimiyet ve gündemi aktif olarak takip etmek, basılı gazetelerde de çevrimiçi gazetelerde de çalışan gazeteciler için olmazsa olmaz kriterdir. İlanda istihdam edilecek gazetecinin çoklu yetenek özelliği taşıması isteği de belirgindir. Sosyal medya bilgisinin olması, canlı haber takibi yapabilmesi, SEO uyumlu haber yazabilmesi gibi nitelikler bir editörden sadece haber yazmasının beklenmediği aynı zamanda yeni medyanın getirilerine de uygun hareket edebilmesi beklentisi içinde olunduğunu göstermektedir. Ayrıca, çoklu ortam üretiminin kapsayıcılığı, gazetecilerin özerk olma kaygısının tersine, ekip çalışmasına vurgu yapma eğilimindedir. Ancak gazeteciliğin temeli olan haber başlı̆̆ı ve özet yazımının en son maddeye koyulması da gazetecilik mesleğinin geleceğinin sorgulanabilir bir durumu ortaya çıkarmaktadır.

Bu sürecin haber üretimini nasıl etkilediği sorulduğunda gazetecilerin bu konudaki görüşleri şu şekilde olmuştur: "Haber üretim süreçlerini hızlandırmış, gazetecileri de anlık düşünme ve üretmeye sevk etmiştir." (Yenisafak.com İnternet Yazı İşleri Müdürü Ersin Çelik). "Kuşkusuz içeriği zenginleştirme ve niteliğini artırmada büyük katkısı oldu bu mecraların. Rutin haberlerin takibinin yanı sıra, haberin kaynağına ve tüm bileşenlerine ulaşıp, renkli ve gazeteye özel haber içeriği üretmekte tecrübeli bir gazeteci için avantaj sunmakta bu mecralar. Bu mecralar haberciliğin temelinde bulunan rekabet olgusunu zorlaştırmakla beraber, haber içinde haber üretimiyle gazeteciliği rekabete sürüklemektedir." (Emekli gazeteci A).

\section{3. Çoklu Yeteneğe Yönelik Olumsuz Yaklaşım}


Gazetecilik görevleri yeniden tanımlanır hale geldikçe, bir dizi sorun gündeme getirilmiştir. Bromley (1997) asıl meselenin çoklu yeteneğin gazetecilikte vasıflı işgücünün ortadan kalktığ1 "az yetenekliliğe" yol açıp açmadığını sorgulamak olduğunu ifade etmiştir. Ayrıca yeni çevrimiçi çalışma kültürü ve yöndeşik haber merkezleri, çok yönlü gazeteciler, son teslim tarihlerinin baskısı (son teslim tarihlerinin yokluğu da denebilir) ve artan rekabet tarafından karakterize edilir.

Kalite sorunu: Yapılan bazı çalışmalar, gazetecilerin daha fazla görevi (bazıları teknik görevlerdir) yerine getirebilmek için daha fazla zaman harcadıklarını, bunun da analiz süresini kısalttığını göstermiştir. Artan rekabet ve hızlı çalışma temposu da bu etkiye katkıda bulunmuştur. Bu gelişmeler, iş yükünün artması, gazetecilerin asıl becerilerinin zayıflaması ve kalite standartlarının düşmesi sebebiyle gazetecilerin üzerlerindeki baskının arttığ1 gerekçesi ile eleştirilmiştir (Cottle, 2003). “Detay habercilik ve araştırma dosyaları açısından olumsuz bir etkilenme söz konusu. Bir an önce haberi yayınlamak ve okuyucuya ulaştırma güdüsü metinleri zayıflatmaktadır." (Yenisafak.com İnternet Yazı İşleri Müdürü Ersin Çelik).

Fenton (2010: 6), internetle bağlantılı bu "yeni gazeteciliğin"; acemilere açık, editoryal kontrolden yoksun, herhangi bir yerden oluşturulabilen, yeni yazma tekniklerini içeren, parçalanmış kitleleri olan bir ağda büyük bir hızla, açık ve tekrarlayıcı olarak işleyen bir yapıda olduğunu iddia etmektedir. Bu konuda görüşülen kişilerin yorumları da şu şekildedir: "Yeni medyanın ortaya çıkması sonrasında özellikle yeni akım gazeteciler, oturduğu yerden, kopyala-yapıştır türünden gazeteciliğe alıştı. Daha doğrusu bunun gazetecilik olduğunu zannetmeye başladı. Evet internet güzel. Evet iyi bir kaynak. Ancak bu hiçbir zaman bir haber kaynağı değil, haberi destekleyecek bilgilerin bir aynası olabilir sadece. Gazeteci adayı, "x" sitesindeki bir haberin kendi haberi olamayacağını bilmeli" (Milliyet gazetesi editörü ve yazarı Mustafa Anıklı). "Kaliteyi düşürmesi söz konusu. Çünkü haberin yayın sürecinde birden fazla aşamasında yer almanın çok sayıda olumsuz yönü var. Mesela haberi yazmada çok iyi olan bir editör yayınlama sürecinde, örneğin iyi bir başlık ve spot çıkarmada aynı performansı gösteremez. Ya da sosyal medya paylaşımlarında bir çarpıcılık ortaya koyamaz. Bu tarz olumsuzlukları hem kendim hem de çalışma arkadaşlarım üzerinden çokça tecrübe ettim." (Yenisafak.com İnternet Yazı İşleri Müdürü Ersin Çelik).

Hız baskısı: Hiza ve artan baskıya yapılan vurgu, haber ajanslarının orijinal haber elde etme konusunda yaşadığı sıkıntıların ne kadar önemli hale geldiğiyle alakalıdır (Scott, 2005; Davies, 2008). Örneğin iki İspanyol medya şirketinde haber merkezlerinin yöndeşmesi üzerine yapılan bir araştırmada özellikle multimedya haberlerin, gazetecilerin zor bir iş olarak gördükleri, zaman baskısı altında çalıştıkları ve iş yükleriyle ilgili olarak endişe duydukları görülmüştür (García Avilés ve Carvajal, 2008: 232). Yoğun çalışma baskısı ile ilgili endişeler, haber merkezlerinin bilgisayarlaştırılması ve dijitalleştirilmesi üzerine yapılan pek çok araştırmada da yinelenmiştir (Rintala ve Suolanen, 2005; Chung, 2007; Ursell, 2001).

Haberturk.com eski Genel Yayın Yönetmeni Yardımcısı Barış Erkaya hızın kendileri üstlerindeki baskısını rekabet ile ilişkilendirmekte ve basılı gazetelerde çalışanlara kıyasla daha çok stres altında çalıştıklarını ifade etmektedir: "Rekabet halindesin diğerleriyle. 
Geleneksel gazetelerde aynı haberi bir kişi bir günde yazarken ben gün için de 10 kere yazıyorum. Belki baştan sona yeniliyorum. Bütün cümlelerini bile değiştirebiliyorum. Burada yapılan iş bu kadar çiğ sözcüklerle ifade edilecek bir iş değil. Ciddi bir emek. Saniyeler için büyük bir stres içinde yapıyorlar. Burada yetişen gazeteci, basılı gazetede çok kaliteli bir iş yapar."

Bilhassa sosyal medyadaki içeriğin hızlı yayılımımın gazetecilik üzerinde olumsuz etkiye sahip olduğu düşüncesine sahip olanlar da vardır. Anonim ve doğru olmayan içeriklerin hızla yayılması gazeteciliğe olan güveni de azaltmaktadır: "Hız gazetecilikte her zaman önemliydi. Ama sosyal medya hız konusunda gazetelere nal toplatır hala geldi. Ancak sosyal medyadaki bu hız bazı sorunları da beraberinde getirmiştir. Her şeyin her şekilde yazılıp söylenebildiği elektronik ortamda fotoğraflarla oynanabildiği ve tüm bunların mahlas ya da takma isimlerle yapilabiliyor olması, bu durumun da sosyal medya izleyicileri arasında genel kabul görüyor olması gazetecilikle ilgili zaten düşük olan güven çıtasını daha da aşağılara düşürmüştür. Yükselen değer sosyal medya olurken konvansiyonel olan medya çok gerilere düşmüştür bu yarışta." (TRT Muhabir).

Stres: Gazetecilik en stresli işlerin başında ilk 10'da yer almaktadır. Özellikle küçük gazetelerde çalışan editörlerin tükenmişlik riski altında olduğu görülmektedir. Gazetecilerin görev ve sorumluluklarının artması, özerkliklerini etkilemekte bu da daha fazla strese ve iş tatminine yol açmaktadır (Reinardy, 2011: 34). Farklı ülkelerde yapılan araştırmalar da gazetecilerin iş tatminlerinin haber merkezlerindeki olumsuz çalışma şartlarından etkilendiğini göstermektedir (Weaver vd., 2007; Nygren, 2011; Raeymaeckers, Paulussen \& De Keyser, 2012). Profesyonel gazeteciler arasında genellikle iş tatmini yüksek olmakla birlikte, yaşanan stres kaynakları arasında maaş, iş yükü, iş güvencesizliği ve terfi beklentilerinin karşılıksız kalması gösterilmektedir. Özellikle yaşanan teknolojik gelişmelerin, daha az personelle daha çok içeriğe, daha kısa sürede daha çeşitli ve fazla göreve, daha az ücret karşılığında daha fazla esnekliğe yol açmaktadır (Deuze, 2007; Cushion, 2007; García Avilés vd., 2004).

Giderek artan sayıda gazetecinin, basım, televizyon ya da radyodan kurumun web sitesi ve mobil haberlere kadar, çoklu dağıtım platformları için çoklu ortam formatlarında (metin, ses, fotoğraf ve video) içerik üretmesi gerektiği söylenebilir. Hem görevlerin artması hem de çevrimiçi mecranın getirdiği hız baskısı gazeteciler de strese yol açabilmektedir.

Yöneticiler çoklu yeteneğin gazetecilerin çalışma hayatlarında strese yol açtıklarını ifade etmektedirler: “Odaklanma sorunu yaşanıyor, birden fazla sorumluluk alınıyor ve gazeteciler daha fazla çalışıyorlar. Bu da bir süre sonra strese hatta bıkkınlığa yani meslekten soğumalara neden oluyor." (Yenisafak.com İnternet Yazı İşleri Müdürü Ersin Çelik).

Maliyet baskısı ve istihdamın daralması: Teknoloji kendi başına bu süreçte baskı unsuru olmamaktadır. Yeni tekniklerin, makinelerin kullanılması ve böylece insan gücünün yerini makinelerin alması teknolojik işsizlik olarak adlandırılmaktadır. Yeni teknolojinin girdiği kesimlerde üretim artarken bu kesimlerde çalışanlar da işsiz kalmaktadır ve bu kesimlerden diğer kesimlere doğru emek akımı başlar (Gediz \& Yalçınkaya, 2000: 164). 
Basın işletmeleri için personel giderleri, toplam gider kalemleri içinde en büyük payı alan gider kalemlerinden biri olma özelliği taşımaktadır. Personel giderlerini kendi içinde; üretim aşamasında ve genel işlerde kullanılan işçiler, işletmenin yönetim kademesinde bulunan ve karar verici pozisyona sahip olan yöneticiler ve içeriğin oluşup okura ulaşmasını sağlayan, bu sayede de ortaya çıkan ürüne bir kimlik kazandıran yazar ve muhabirler olarak gruplandırmak mümkündür (Bulunmaz, 2011).

Zamanla çevrimiçi sürümleri bulunan konvansiyonel gazeteler personel giderlerini azaltmak için hem konvansiyonel gazete için hem de çevrimiçi gazete için içerik üretebilecek, çoklu yeteneğe sahip gazetecileri bünyesine katmaya başlamışlardır. The National Union of Journalist'in 2007 yılına yayınladığ1 'Shaping the Future: Commission on Multi-Media Working Report'a göre, gazetecilerin yüzde 75'i iş yüklerinin; yüzde 37'si ise çalışma saatlerinin arttığını belirtmektedir. Ayrıca araştırmaya katılan NUJ üyelerinden yalnızca 1/4'ü çalışanlarına bu tür bir çalışmadan dolayı ek ücret ödediklerini belirtmişlerdir (https://www.nuj.org.uk/documents/shaping-the-future/, 14 Eylül 2018).

Teknolojik değişimlerin istihdama olan etkileri zaman içerisinde dile getirilmiştir. Milliyet Gazetesi yazı işleri eski müdürlerinden Hasan Çakkalkurt bilgisayarlaşma ile yaşadıklarını şöyle aktarmıştır: "Bilgisayara geçmenin çalışanlar açısından bir faturası var. Bizim dizgi servisimiz yaklaşık 25 kişiydi. Montaj servisimiz de bir o kadardı. Düzeltme servisimiz 15-20 kişi kadardı. Yaklaşık 50-60 kişilik bir baskı öncesi hazırlık teknik ekibi vardı. Bunların sayısı sanıyorum bugün 15'e indi. Ayrılanlar oldu, gazete içinde yer değiştirenler oldu. Promosyona ağırlık verdik ve bir kısmı oraya kaydı" (Vural \& Gürcan, 1994: 45). Yönetimlerin maliyetleri düşürme ve üretimi artırma konusundaki saplantıları da, iş yükünün artmasına sebep olmaktadır.

Özellikle çoklu yetenek, yani birçok kişinin yapacağı bir işin tek bir kişi tarafından yapılması, basın işletmelerinde personel sayısında da daralmaya gidilmesine yol açmıştır. "Bilgisayar ve ağ teknolojisi ile birlikte dizgi ve baskı gibi iş alanlarında daralma yaşanmıştır. Çevrimiçi gazetecilik basın işletmelerinde bazı alanlardaki işgücü sayısında azalmaya gidilmesine sebep olmuştur. Özellikle teknik personel konusunda bir azalma söz konusudur" (Yenisafak.com İnternet Yazı İşleri Müdürü Ersin Çelik).

Gediz ve Yalçınkaya (2000), teknolojik gelişmelerin kısa dönemde istihdam azaltıcı, uzun dönemde de istihdam arttırıcı bir rol oynadığını ifade etmektedirler. Uzun dönemde yan çalışma dalları ortaya çıkmakta ve işgücünü yeniden değerlendirme fırsatı doğmaktadır. Örneğin basın işletmelerinde artık sosyal medya, veri madenciliği ve arama motoru optimizasyonu gibi alanlarda uzmanlar istihdam edilmektedir (Çetinkaya, 2016: 247).

Her ne kadar çoklu yetenek anlayışının medya organizasyonlarındaki maliyeti düşürdüğü düşünülse de çalışanların çalışma koşulları açısından değişme olmadıkça verimliliğin sağlanamayacağı da ortadadır.

\section{Sonuç ve Değerlendirme}


Haber merkezlerinin yöndeşmesi ve gazetecilikteki çoklu ortam eğilimi, gazetecilerin çoklu yeteneğe sahip olma gerekliliğini ortaya çıkarmıştır. Konvansiyonel gazetelerin haber merkezlerinde çalışan kişilerin çevrimiçi gazeteler için de çalışmaya başlamaları, bu mecranın özelliklerine uygun haber üretme pratikleri geliştirmelerine yol açmıştır. Ayrıca yeni medyanın sahip olduğu çoklu ortam özelliği, gazetecilerin haberi yazmalarının yanında onu yayınlanacağı platforma uygun hale getirme, içeriği videolar, görseller ve sesli materyallerle zenginleştirmeleri gereğini de ortaya çıkarmıştır.

Yapılan görüşmeler sonucunda gazetecilerin bilhassa çevrimiçi gazetecilikte çoklu yetenek gerekliliğinin farkında oldukları ve buna dikkat çektikleri gözlemlenmiştir. Çoklu yeteneğin haber üretim sürecine etkileri, işin hızlanması, gazetecileri anlık düşünmeye ve üretmeye sevk etmesi, içeriğin zenginleşmesi ve çeşitlenmesi bağlamında dile getirilmiştir.

Çevrimiçi gazetecilik açısından çoklu yeteneğin en yaygın olduğu biçim, çoklu ortama yönelik içerik zenginliği yaratmanın yanında, o içeriği arama motorlarına uygun hale getirme ve sosyal medyada paylaşabilme olarak görülmektedir. Artık bir editörden sadece o haberi yazması ve düzenlenmesi beklenmemekte, o haberi arama motorlarında üst sıralarda çıkartacak anahtar kelimeleri kullanması ve sosyal medyada görüntülemeyi artıracak şekilde paylaşması beklenmektedir.

Çoklu yetenek, daha fazla üretkenlik ve iş tatmini sağlamasının yanında hız baskısı ve rekabet nedeniyle gazetecilerde strese ve içerik kalitesinin düşmesine yol açtığ 1 gerekçesiyle eleştirilmektedir. Yoğun ve esnek mesai saatleri, çevrimiçi habercilikte haberlerinin raf ömrünün kısa olması sebebiyle anında haberi girme gerekliliği gibi durumlar gazetecileri stres altına sokmaktadır. Haberin kalitesi konusundaki şüpheler de devam etmektedir. Bazı haberciler bu yönlü bir çalışma pratiğinin "zanaat" editörlüğü yaratmayacağını vurgulamaktadırlar. Ancak yine de tüm gazetecilerin bu yeni çalışma yöntemini benimsediği söylenemez.

Üretim ve personel maliyetlerini azaltma ihtiyacı, idarecilerin çoklu yeteneği bir araçtan ziyade bir amaç olarak görmelerine yol açmaktadır. Bu durum teknolojik bir determinizmden ziyade ekonomi baskısı olarak ortaya çıkmaktadır. Özellikle dünyada ve Türkiye' de basılı hayatlarına son vermeleri, bu tür bir ekonomik baskının giderek artacağına da işaret etmektedir.

Sosyal medya ve arama motoru uygulamalarıyla farklı bir boyut kazanan çoklu yetenek, yöndeşik haber merkezleriyle de evrim geçirmektedir. Basılı gazetelerin kapanması, çevrimiçi gazetecilikteki ivmenin giderek artacağını göstermektedir. Yeni medyanın sahip olduğu özellikler ve güncellemeler göz önüne alınarak gazetecilik eğitiminin revize edilmesi ve sektörün ihtiyaçlarına yönelik gerekli beceriye sahip gazetecilerin yetiştirilmesi önem arz etmektedir. Sürekli yenilenmiş ve gözden geçirilmiş eğitim müfredatlarının uygulanması, sektördeki işgücü gereksinimin karşılanmasına yardımcı olurken, gazetecilik mesleğinin etik ilkelerine uyan ve özgünlügünü devam ettiren gazetecilerin yetişmesini de sağlayacaktır. Bunun uzun vadede çevrimiçi gazetecilikteki nitelik sorununu çözeceği öngörülebilir. 


\section{KAYNAKÇA}

Anderson, A., 2003, Environmental activism and news media. Cottle, S. (Ed.), News, Public Relations and Power, London: Sage.

Bromley, M. (1997). The end of journalism? Changes in workplace practices in the press and broadcasting in the 1990s. A journalism Reader, Eds. M. Bromley \& T. O'Malley, London, UK: Routledge, 330-350.

Bulunmaz, B. (2011). İnternet gazeteciliğinin medya dünyası içindeki rolü ve ekonomik boyutları. Marmara İletişim Dergisi, Sayı 18, 27-46.

Chung, D.S . (2007). Profits and perils: Online news producers' perceptions of interactivity and uses of interactive features, Convergence, 13(1), 43-61.

Cushion, S. (2007). Rich media, poor journalists: Journalists' salaries. Journalism Practice, 1(1), 120-129.

Çetinkaya, A. (2016). Günümüz medya ekonomisi çerçevesinde çevrimiçi gazetecilik ve reklam ilişkisi. Yayımlanmamış Doktora Tezi, İstanbul, İstanbul Üniversitesi S.B.E.

Davies, N. (2008). Flat earth news: An award-winning reporter exposes falsehood, distortion and propaganda in the global media, London: Chatto and Windus.

Deuze, M. (2007). Media Work. Cambridge: Polity Press.

Erdal, I. J. (2009). Repurposing of content in multi-platform news production: towards a typology of cross-media journalism. Journalism Practice, 3(2): 178-195.

Fenton, N. (ed), 2010, New media, old news? London and Thousand Oaks, CA: Sage.

Gans, H.J. (1978). Deciding What's News: A Study of CBS Evening News, NBC Nightly News, Newsweek, and Time, Chicago, IL: Northwestern University Press.

García Avilés, J.A. and Carvajal, M. (2008). Integrated and cross-media newsroom convergence: two models of multimedia news production - the cases of novotécnica and la verdad multimedia in Spain, Convergence, 14(2), 221-239.

Gediz, B. ve Yalçınkaya, H. (2000). Türkiye'de istihdam-işsizlik ve çözüm önerileri: Esneklik yaklaşımı, Celal Bayar Üniversitesi, İ̈BF- Yönetim ve Ekonomi Dergisi, Sayı: 6, 161183.

Gordon, R. (2003). The Meanings and Implications of Convergence. K., Kawamoto, Lanham: Rowman and Littlefield (Eds.), Digital Journalism: Emerging Media and the Changing Horizons of Journalism, 57-73.

Huang, E., Rademakers, L., Fayemiwo, M.A. \& Dunlap, L. (2004). Converged journalism and quality: A case study of the tampa tribune news stories, Convergence, 10, 73-91.

Karahisar, T. (2012). Türkiye'de medya sektörü ve gazeteciler. Bursa: Ekin Yayınevi.

Lee-Wright, P., Philips, A. and Witschge, T. (2011). Changing Journalism, London: Routledge.

Muhabir Habercinin Temel Kitabı. (2018). İstanbul: Anadolu Ajansı Yayınları.

Nygren, G., 2011, Passing through journalism? Journalism as a temporary job and professional institutions in decline. B. Franklin, and D. Mensing (Eds.), Journalism Education, Training and Employment, London: Routledge, 207-221.

Pavlik, J. V. (2001). Journalim and new media, New York: Columbia University Press. 
Quinn, S. (2005). Convergence's fundamental question. Journalism Studies, 6(1), 29-38.

Raeymaeckers, K., Paulussen, S. \& De Keyser, J. (2012). A survey of professional journalists in Flanders (Belgium), D. Weaver and L. Willnat (Eds.), The Global Journalist in the 21st Century, London: Routledge.

Reinardy, S. (2011) Newspaper journalism in crisis: Burnout on the rise, eroding young journalists' career commitment, Journalism, 12(1), 33-50.

Rintala, N. \& Suolanen, S. (2005). The implications of digitalization for job descriptions, competencies and the quality of working life, Nordicom Review, 2/2005, 53-67.

Saltzis K. \& Dickinson R. (2008). Inside the changing newsroom: Journalists' responses to media convergence aslib proceedings. New Information Perspective, 60(3): 216-228.

Saltzis, K. (2012). Doing journalism online: how uk news organizations have adapted in the age of the internet, E. Siapera and A. Veglis (Eds), The Handbook of Global Online Journalism, UK: Wiley-Blackwell, 462-477.

Schudson, M. (2005). Autonomy from what?, R. Benson, and E. Neveu (Eds.), Bourdieu and The Journalistic Field Cambridge: Polity, 214-223.

Scott B. (2005). A contemporary history of digital journalism. Television and New Media, 6(1), $89-126$.

Singer, J.B., (2004). Strange bedfellows? The diffusion of convergence in four news organizations, Journalism Studies, 5(1), 3-18.

Stone, M. (2002). The backpack journalist is a "mush of mediocrity", Online Journalism Review, http://www.ojr.org/ojr/workplace/1017771634.php, internet adresinden 12 Eylül 2018 tarihinde edinilmiştir.

Tanner, A. \& Duhe, S. (2005). Trends in mass media education in the age of media convergence: Preparing students for careers in a converging news environment, Studies in Media and Information Literacy Education, 5(3), 1-12.

The National Union of Journalist Shaping the Future: Commission on Multi-Media Working Report (2007). https://www.nuj.org.uk/documents/ shaping-the-future/, internet adresinden 15 Şubat 2016 tarihinde edinilmiştir.

Tuchman, G. (1978). Making the news: A study in the construction of reality, New York: FreePress.

Ursell, G.D.M. (2001). Dumbing down or shaping up? New technologies, new media, new journalism, Journalism, 2(2), 175-196.

Vural, A.M. \& Gürcan, H.İ. (1998). Türk basınında teknoloji ve insan, Eskişehir: Anadolu Üniversitesi Yayınları.

Weaver, D.H., Beam, R.A., Brownlee, B.J., Voakes, P.S. \& Wilhoit, G.C. (2007). The american journalist in the 21st century: U.s. news people at the dawn of a new millennium, mahwah, NJ: Lawrence Erlbaum.

Wilkinson, Jeffery S., August E. Grant \& Douglas J. Fisher, (2013). Principles of convergent journalism, New York: Oxford University Press.

www.kariyer.net, internet sitesinden 19 Eylül 2018 tarihinde edinilmiştir. 